\title{
Fitness to work: a comparison of European guidelines in the offshore wind industry
}

\author{
Alexandra Marita Preisser*, Rosalie Victoria McDonough*, Volker Harth
}

Institute for Occupational and Maritime Medicine, University Medical Centre Hamburg-Eppendorf, Germany

\begin{abstract}
Occupational medicine must be able to meet the challenges of rapidly changing technologies and innovations, including the implementation of health and safety standards for physically and psychologically demanding work environments. One such challenge is presented by the offshore wind industry. Here, the demand for "Fitness to Work" regulations for potential employees is justified. An appropriate evaluation has to consider the two aspects "fit for task" and "fit for location and conditions". Guidelines for the fitness testing of offshore employees have been created by various national organisations. The guidelines of the industry organisations of the United Kingdom (Oil \& Gas UK) and the Netherlands (NOGEPA), as well as the Norwegian Directorate of Health, were developed for employees of offshore oil and gas platforms. In Germany, however, a medical guideline for fitness testing specific to workers in the offshore wind industry has recently been created. Such recommendations should be made on the basis of accident statistics and rescue reports, but there are only limited data available. In this paper, we present, compare and discuss the content and features of the various guidelines, as well as their recommendations for medical assessment.
\end{abstract}

(Int Marit Health 2016; 67, 4: 227-234)

Key words: fitness to work, offshore wind energy, occupational health and safety, renewable energy, physical examination, risk analysis

\section{INTRODUCTION}

Occupational health is an area of medicine devoted to the physical, mental and emotional health and safety of individuals in terms of all dimensions of their working environments and responsibilities. The speciality includes advisory and educational assistance in support of workplace safety and the prevention of occupational injuries and disease, the development and application of fitness assessments for work requirements, as well as treatment and rehabilitation for injured or sick workers to assist them in their return to work.

The field of occupational medicine also has to meet the challenges of rapidly changing technologies and innovations in a variety of modern industrial sectors, as well as wholly new sectors, where the risks of the workplace and its job requirements are often not known or foreseeable. Advancements in the study of the pathomechanisms of disease have permitted much deeper and more expansive insights into the dangerous consequences of poor workplace safety practices (or, in some cases, the absence of regulations).

In certain occupations, such as firefighting, commercial diving and remote-location work, the necessity of "Fitness to Work" is readily understandable. In fact, however, there are a wide range of occupations that subject workers to often difficult and potentially risky physically and psychologically demanding tasks. For each occupation, therefore, it is important to determine the nature and extent of these demands, as well as the capacity of employees to deal with them. In line with this, "Fitness to Work" should not be confused with general medical-surveillance or health-promotion programs; rather, it deals directly with a central question: "Can this person do the assigned tasks safely and repeatedly without foreseeable risk to their health and safety or that of their colleagues, third parties and company assets?" [1].

Alexandra Marita Preisser, Deputy Director, Head of Clinical Occupational Medicine, Physician for Occupational Medicine, Physician for Internal Medicine and Pneumology,

Allergology, Institute for Occupational and Maritime Medicine, University Medical Centre Hamburg-Eppendorf, Germany, e-mail: a.preisser@uke.de

* Alexandra M. Preisser and Rosalie V. McDonough are equally contributing first authors. 
"Fitness to Work" is usually assessed via a multi-level physical examination (including tests of functional capacity) that is specific to the task at hand. The examination is designed to apply equally to all persons performing the work, and should produce consistent results upon re-testing. Such an evaluation must also take into account "direct risks" (i.e., those of the working conditions themselves) and "indirect risks" (i.e., those that arise due to logistical challenges). Put another way, this is the difference between measures of "fit for task" and "fit for location and conditions" [1].

As with most types of evaluations, there can be special requirements for, as well as limitations to, their implementation. Some require specialist knowledge (of both the medical conditions and the workplace), while the examinations can also be time-consuming and costly. Perhaps most importantly, they are restricted to a single moment in time, which means they cannot be predictive of the future health conditions of any given worker. This important limitation to "entry" or "one time" examinations, therefore, underlines the importance of regular, ongoing health testing throughout the duration of employment.

\section{WIND ENERGY}

Over the past few decades, the major expansion of the renewable energy sector has created a range of new employment opportunities for tradesmen and technicians. Wind energy has become one of the major alternatives ("green energy" versus fossil fuels and nuclear energy), and more and more "turbines" and "wind farms" have been constructed and installed in numerous onshore and offshore locations across the world. Thus far, Europe has been a leader in this field, with such countries as Denmark fulfilling as much as $40 \%$ of their electricity needs from this "green" source [2]. While on a global scale wind energy currently accounts for only about 3\% of total energy production, the rate of its use is nonetheless rapidly growing [2]. Today, wind energy meets approximately $10 \%$ of Europe's electricity demand [3]. The United Kingdom (45.9\% of installed offshore wind power in Europe / $5.1 \mathrm{GW})$, Germany (29.9\% / 3.3 GW), and Denmark (11.5\% / 1.3 GW) currently dominate the European offshore sector of wind energy, having constructed between them the largest offshore wind farms internationally with the greatest capacities $[2,4]$. Other countries, including the Netherlands, Norway, Belgium and Sweden also generate a substantial amount of their energy from offshore wind-powered installations. Beyond Europe (and to some degree because of European initiatives), wind-energy developments have begun to be pursued more earnestly in China (29 GW), Japan, South Korea and Taiwan, albeit more slowly in Canada and the United States [2]. Other major markets, including India and Brazil, are now in the early stages of planning.

\section{WIND ENERGY OFFSHORE INSTALLATIONS}

Wind energy turbines and offshore-platforms vary substantially in design and size. Crew size also varies, and the number of employees working at a time often determines the presence or absence of medical facilities, including trained nurses, examination areas and sick beds. The working and living conditions on the offshore platforms are typically strenuous and often challenging in terms of health considerations. Employees must be able to perform heavy manual labour, including windlass work and frequent climbing of ladders and stairs. Part of the work must be performed at great heights and under often rapidly changing weather conditions. Exposure to multiple physical stressors, including extreme temperatures, high humidity, continuous noise and vibrations, and potentially dangerous chemicals is generally unavoidable [5]. Wind masts operate continuously, on a workforce basis of 12-h alternating shifts [6]. Working tours typically last 2 to 3 weeks, with travel to and from the platforms by helicopter or boat. This form of shift work often results in interrupted sleep time, long absences from home, and restricted privacy in the often cramped, shared living quarters [7]. In combination, these conditions are conducive to a variety of potentially high-risk situations, the consequences of which can be grave. For these reasons, it is important to develop a standard set of guidelines to ensure that platform workers have the best possible health qualifications to perform the duties required [8].

\section{ACCIDENT AND RESCUE STATISTICS}

Assessment of health indicators of workers and workplaces in this sector can prove difficult, as administrative records of accident statistics and health and safety practices are usually not published. The present research effort (which included a thorough online search) was only able to find four published articles on the incidence of accidents and illnesses in offshore-platform working environments. Moreover, only one of these [9] dealt with the wind-energy sector, while the remainder were focused on the offshore oil and gas industry [10-12]. The single study dealing with wind energy platforms indicates that the majority of illnesses associated with the offshore industry affect the musculoskeletal system (19\%), followed by gastrointestinal disorders (15\%), and respiratory and nervous systems (both 13\%); $60 \%$ of health-problem incidents were due to injury [9]. It is important to note, however, that fully $65 \%$ of these injuries occurred on construction vessels, while only $16 \%$ occurred on the actual wind masts.

In order to gain more insight into the causes and mechanisms of injury and illness, as well as to facilitate data acquisition and the creation of a more reliable database, the BG Hospital Hamburg has initiated the development of a Central Medical Offshore Register (CeMOR) [13, 14]. 
This project may contribute substantially to epidemiological knowledge and quality assurance concerning occupational healthcare in the offshore industry. In a preliminary retrospective study, Stuhr et al. [13] analysed 319 medical incidents which happened on German offshore wind farms in the years 2008-2012 (190 traumatic injuries, 123 acute illnesses and 4 fatalities). Dethleff et al. [15] further evaluated 39 of these medical incidents involving offshore medevacs on the wind farm BARD Offshore 1 (approx. $100 \mathrm{~km}$ off the German coast, comprising a total area of roughly $60 \mathrm{~km}^{2}$ ) for the period between August 2011 and December 2013. In 19 cases, the medevacs responded to traumatic injuries, whereas 16 events were due to acute illness, the most frequent of which (9) being cases of internal medicine. In 4 cases, the type of the medical emergency remained unclear [15].

\section{AIMS}

The objective of this paper is to draw comparisons among countries with established protocols in place for assessing "Fitness to Work" that are specific to the offshore wind energy sector or to similar workplace surroundings. To this end, we investigated and determined where the major discrepancies lie among currently established guidelines, with the longer-term goal of developing an international document that would allow workers to move freely between job sites across international offshore operations, at least in terms of their "Fitness to Work" requirements. The focus is on Germany, Norway, the Netherlands and the UK, not only because they make up the majority of windmill operators globally, but also because each of these countries has published regularly updated and public-access guidelines for examining physicians to aid in the assessment of health for an extensive inventory of medical conditions.

\section{MATERIALS AND METHODS}

To gain the necessary information required for this analysis, a point-by-point evaluation of guidelines from Germany [16], the Netherlands [17], Norway [18], and the UK [19, 20] was undertaken. Only two of these five guidelines [16, 20] are specific to the offshore wind industry, the remaining three having been drafted for the oil and gas sector. However, because these areas share many similarities, particularly with regard to the physical and psychological strain that their respective workers are subjected to, they have been accepted as equivalent for the purposes of this study. For the required background information, a subsequent literature review was done of reports found and downloaded from the Internet. In addition, a variety of databases were scanned for the following key search terms: fitness to work, offshore wind energy, occupational health and safety, renewable energy, oil and gas industry, physical examina- tion and risk analysis. Finally, the research also included personal communications with international experts, which yielded important supplementary information and insights.

\section{RESULTS}

The comparison of the German, Dutch, Norwegian and British guidelines revealed that there are few differences in the national health requirements for offshore work in the oil and gas and wind energy industries. Indeed, the Dutch and Norwegian guidelines make direct reference to the "Oil \& Gas UK" publication and, in some respects, are identical.

\section{LOCATION}

In Europe, platforms are spread out among the Atlantic Ocean (22.5\%), the North (63.3\%) and Baltic Seas (14.2\%) [21], and are almost exclusively to be found in the Exclusive Economic Zone (EEZ, an area that stretches from the baseline out to 200 nautical miles, approx. $370 \mathrm{~km}$, from the coast). Because national law is not always applicable in this area, in some cases (e.g., Germany), special extended coverage clauses have been developed [16]. Together, these platforms make up more than $91 \%$ of all European offshore wind installations [2].

\section{CREW SIZES AND FACILITIES}

Depending on the design and size of the platform, crew size varies greatly. In the Netherlands, installation crews range from less than 10 to approximately 200 people. The platforms run $24 \mathrm{~h}$ and the employees work in 12-h alternating shifts over periods of typically 2 to 3 weeks. Accommodation is in 2-bed cabins. There are also recreational facilities, including television, a small gym and other "social facilities". Alcohol is not allowed anywhere on the premises. For crew sizes of 25 and more, a trained nurse is required, as well as a sick bay/examination area with 1 to 2 beds [17].

In Norway, crews can be as small as 30 members, with the largest comprising 300-350. The usual shifts are 2 weeks on and alternating 3 and 4 weeks off, while others work 2 weeks on and 4 weeks off. Most employees have a single cabin or a shared cabin with a person working on opposite shifts. Regardless of crew size, all fixed offshore installations must have a paramedic (a qualified trained nurse) [18].

Installation crews in the UK are anywhere from fewer than 20 to 250 members in size, also working in 12-h shifts over 24-h operating periods. As in the Netherlands, tours are typically 2 to 3 weeks long, and recreational facilities are provided. Most platforms have a fully equipped sick bay with an examination area, a 1 to 2-bed ward and a bath to treat hypothermia. Medical equipment includes: electrocardiogram (ECG), defibrillator, a gas-powered ventilator, a pulse oximeter, and emergency medication. The paramedic 
may be authorised by an on-shore physician to prescribe the medication [19].

Reports on the German platform environment and facilities were difficult to obtain, with very little information to be found. One example is the BARD Offshore 1 platform, installed in the summer of 2010 and operational since 2013 , which accommodates a maximum of 40 people in sleeping bunks and provides a fitness room [22, 23].

\section{THE GUIDELINES}

Different governing bodies oversee the responsibility for the establishment of the guidelines. In Germany, they are developed by the German Society for Occupational and Environmental Medicine (DGAUM) and the German Maritime Health Association (DGMM e.V., "Offshore" working group), alongside with experienced occupational physicians, representatives of Employer's Liability Insurance Association, industry organisations and offshore employees [16]. The guidelines are based on the German Occupational Health and Safety Act. Examinations are performed by a specialist in occupational medicine. The physician must have knowledge of the offshore work environment, the tasks of the individual employees and the demands of the required safety training [16].

In the UK, the guidelines are prepared and written by "Oil \& Gas UK" [19]. In 2013, RenewableUK released a subsequent set of guidelines specific to the wind energy sector and its risks [20]. These are limited to medium and large wind turbines that are either onshore or "near offshore" (where travel by boat is less than $2 \mathrm{~h}$ and there are no overnight stays; travel via helicopter is excluded). Examinations are performed by a physician who is approved by "Oil \& Gas UK" and whose name appears on the current "Oil \& Gas UK" list of appointed doctors, or by a qualified occupational health nurse, often under direct supervision of an occupational physician [20]. The Dutch guidelines are produced by the Netherlands Oil and Gas Exploration and Production Association (NOGEPA) [17] and make reference to the "Oil \& Gas UK" guideline [19]. Examinations are performed by physicians who are approved by NOGEPA and whose names appear on the current NOGEPA list of appointed doctors. An annual half-day training program provides knowledge of the offshore environment and remote medicine, and attendance is recommended at least every 2 years. In addition, certified physicians must perform at least 6 offshore medical examinations per year, in accordance with the principles of the risk-based approach embodied in the guidelines. In Norway, the guidelines are produced by the Norwegian Oil and Gas Association (formerly OLF) under the approval of the Norwegian Directorate of Health [18]. Forms to be filled out by the examining physician are prepared by the County Governor of Rogaland and are also subject to approval by the Norwegian Directorate of Health. Again, reference is made to the "Oil \& Gas UK" document [19]. Examinations are performed by a practitioner with a Norwegian medical license who also holds a special authorisation/certification (i.e., "petroleum doctor"). This is a regulation that came into effect in January 2014 and involves a largely internet-based training program that grants a 3-year initial certification [18].

\section{THE MEDICAL ASSESSMENT}

In all cases, the medical assessment is to be performed prior to employment and thereafter at 2-yearly intervals, unless a specific medical condition or occupation requires more frequent examination as recommended by the guidelines. Absence due to injury or illness may also require re-examination, depending on the duration of the absence [16]. Because the Dutch guidelines [17] so closely follow the UK framework [19], reference will only be made to the latter (unless specific differences are found between the two).

The assessment always includes proof of identity and a comprehensive medical, social and occupational history. In addition to a standard clinical examination, including blood pressure and heart rate measurements, the assessment will usually consist of urine and blood analysis, spirometry, dental status, an ECG and stress-ECG, or a test of load-bearing or aerobic capacity, visual acuity, audiometry and bodymass index measurement. Whether all tests are performed is often left to the physician's discretion and dependent on the medical status/history of the person in question. For additional groups of people, including catering crew, crane operators, pregnant workers and visitors, special recommendations are often included in the guidelines. It is important to note that the final decision of whether or not a person may work rests not with the examining physician, but with the employer or operator of the company or wind farm that is to be visited. Table 1 shows the topics of the medical assessment and medical history. The conducted "point-by-point" comparison of the documents, focused on the medical assessment, is shown in Table 2, with selected 'Differences Among the Guidelines'.

\section{ALCOHOL DEPENDENCE AND DRUG ABUSE}

An example of the recommendations given to physicians in the various documents is provided in the following chapter concerning alcohol addiction: in all cases, current drug and/or alcohol addiction or abuse is not acceptable. In addition, to work in Germany, a person who suffered a past addiction must demonstrate a minimum of a 1-year abstinence. In Norway, a person who has completed or is currently in rehab may be granted a certificate that is subject to risk assessment. The person must demonstrate that he or she has been drug-free for at least 1 year and 
Table 1. The medical assessment (comparisons for topics in bold are shown in detail in Table 2)

\begin{tabular}{|c|c|c|c|c|}
\hline Physical examination & Cardiovascular system & Nervous system & Respiratory system & Gastrointestinal system \\
\hline $\begin{array}{l}\text { - Physical fitness } \\
\text { - Pulmonary function } \\
\text { - Obesity } \\
\text { - Hearing } \\
\text { - Sight } \\
\text { - Visual acuity } \\
\text { - Monocular vision } \\
\text { - Diplopia } \\
\text { - Visual fields } \\
\text { - Colour vision } \\
\text { - Medical history } \\
\text { - Musculoskeletal } \\
\text { conditions } \\
\text { - Limb prostheses } \\
\text { - Joint replacements } \\
\text { - Ear, nose and throat } \\
\text { - Hearing } \\
\text { - Balance } \\
\text { - Eyes } \\
\text { - Skin } \\
\text { - Dental health }\end{array}$ & $\begin{array}{l}\text { - Ischaemic heart disease } \\
\text { - Cardiac arrhythmias } \\
\text { - Pacemakers/implanta- } \\
\text { ble cardioverter } \\
\text { defibrillators (ICD) } \\
\text { - Hypertension } \\
\text { - Congenital heart } \\
\text { disease } \\
\text { - Valvular heart disease } \\
\text { - Peripheral circulation } \\
\text { - Pulmonary circulation } \\
\text { - Cerebro-vascular } \\
\text { disorders } \\
\text { - Allergies and } \\
\text { anaphylaxis } \\
\text { - Medications } \\
\text { - Vitamin K antagonists } \\
\text { - Medication impairing } \\
\text { attentiveness } \\
\text { - Immunosuppressive } \\
\text { medications }\end{array}$ & $\begin{array}{l}\text { - Epilepsy, single seizures, } \\
\text { loss of or reduced } \\
\text { consciousness } \\
\text { - Chronic neurological } \\
\text { disorders } \\
\text { - Migraines } \\
\text { - Narcolepsy/sleep } \\
\text { disorders } \\
\text { - Psychiatric disorders } \\
\text { - Mild anxiety or depressive } \\
\text { disorders } \\
\text { - Psychoses - including } \\
\text { bipolar disease and } \\
\text { schizophrenic disorders } \\
\text { - Personality, behavioural, } \\
\text { and developmental } \\
\text { disorders } \\
\text { - Alcohol dependence and } \\
\text { drug abuse }\end{array}$ & $\begin{array}{l}\text { - Obstructive or } \\
\text { restrictive pulmonary } \\
\text { disease } \\
\text { - Asthma } \\
\text { - Pneumothorax } \\
\text { Endocrine disorders } \\
\text { - Insulin-dependent } \\
\text { diabetes mellitus } \\
\text { - Non-insulin-dependent } \\
\text { diabetes mellitus } \\
\text { - Other endocrine } \\
\text { disorders } \\
\text { Diseases of blood } \\
\text {-Anaemia } \\
\text { - Polycythaemia } \\
\text { - Haemophilia and other } \\
\text { bleeding disorders } \\
\text { Organ transplants }\end{array}$ & $\begin{array}{l}\text { - Peptic ulceration } \\
\text { - Oesophagitis and gastritis } \\
\text { - Inflammatory bowel } \\
\text { disease } \\
\text { - Hernia } \\
\text { - Haemorrhoids, fistulae } \\
\text { and fissures } \\
\text { - Uncomplicated stoma } \\
\text { - Liver disease } \\
\text { - Chronic or recurring } \\
\text { pancreatitis } \\
\text { - Biliary tract disease } \\
\text { Genitourinary system } \\
\text { - Renal calculi } \\
\text { - Chronic renal disease } \\
\text { - Other diseases of the } \\
\text { genitourinary tract } \\
\text { Infectious diseases } \\
\text { Malignant neoplasms }\end{array}$ \\
\hline
\end{tabular}

must agree to random testing for a period of 2 years. It is recommended to restrict the certificate validity to 6 months. Requirements for work in the UK are stricter: the individual must have undergone treatment for alcohol addiction and be participating in an on-going rehab program; medical examination and lab results (e.g., mean corpuscular volume and liver function) must show improvement; a report must be obtained from the treating physician(s); and the individual must demonstrate compliance and agree to set treatment goals. Furthermore, the certificate should be restricted to 3 months.

\section{APPEALS}

In certain guidelines, an appeal process for unsuccessful candidates has been established. In Norway, for example, referrals for reassessment can be made within 3 weeks to the complaints commission, a panel consisting of 4 members who have been appointed by the Norwegian Directorate of Health. The person making the appeal is allowed to attend the appeal process with representation, however the decision agreed upon by the committee is final [18]. In the UK, the review process consists of a thorough discussion between the examinee and the doctor, as well as a written evaluation. When necessary, a third-party review from an "Oil \& Gas UK"-appointed medical advisor will be initiated [19]. In the Netherlands, when an applicant is unsuccessful, a re-evaluation may be performed by the NOGEPA doctor, followed by a peer-review process [17]. Conflict cases in Germany are dealt with in a similar manner; the examinee may receive a second opinion from a member of DGAUM, or specifically the offshore group of the DGMM [16].

\section{DISCUSSION}

\section{RATIONAL BEHIND WORKPLACE MEDICAL TESTING AND FITNESS TEST SELECTION}

Due to the previously described hazards associated with the wind energy workplace, the usefulness of a "Fitness to Work" screening program should be apparent. A well-designed process helps minimize risk and liability, and determines whether employees are capable of carrying out their selected duties. It is also important, however, that this same process does not lead to the unnecessary exclusion of individuals from work they could carry out safely and productively. An example where such a situation could arise is in the load-bearing and aerobic capacity requirements; more specifically, the tests chosen to measure these parameters. Together, these present an interesting variation among the guidelines. The German guideline determines physical fitness via cycle ergometry, while the Dutch and British guidelines recommend the Chester step test. In Norway, the choice of test is left up to the examining physician. Indeed, when considering an accurate measure of physical fitness, the Chester step test often appears to be the method of choice. It presents an attractive alternative to the "gold standard" direct measure of oxygen consumption under maximal exercise, for example on a treadmill or stationary bike, as it requires minimal equipment and is relatively easy to conduct. The values from the test were shown to provide a good estimate of aerobic capacity in males and females of varying ages and fitness levels [24]. Using an equation developed by the American College of Sports Medicine and confirmed for accuracy by Latin et al. [25], testers are able 
Table 2. Selected differences among guidelines. The table presents an abbreviated version of the varying requirements for people with more common conditions (ischaemic heart disease, hypertension, obesity, diabetes mellitus and obstructive lung disease), as well as the form of testing used to determine fitness

\begin{tabular}{|c|c|c|c|c|}
\hline & Germany & Norway & UK (Oil \& Gas) & The Netherlands \\
\hline $\begin{array}{l}\text { Stress/fit- } \\
\text { ness test }\end{array}$ & Cycle ergometry & $\begin{array}{l}\text { Examining physician's } \\
\text { choice }\end{array}$ & $\begin{array}{l}\text { Chester step test (or cycle ergometry } \\
\text { or physiological laboratory testing) }\end{array}$ & Chester step test \\
\hline $\begin{array}{l}\text { Asthma/ } \\
\text { /COPD } \\
\text { (Spirometry) }\end{array}$ & $\begin{array}{l}\text { Acceptable: } \\
\text { FEV1 }>70 \% \text { pred. and } \\
\text { FVC }>70 \% \text { pred. }\end{array}$ & $\begin{array}{l}\text { Acceptable: } \\
\text { FEV } 1>60 \% \text { pred. and } \\
\text { FVC }>70 \% \text { pred. }\end{array}$ & $\begin{array}{l}\text { Acceptable: } \\
\text { FEV1 }>60 \% \text { pred. and } \\
\text { FVC }>75 \% \text { pred. }\end{array}$ & $\begin{array}{l}\text { Acceptable: } \\
\text { FEV1 }>60 \% \text { pred. and } \\
\text { FVC }>75 \% \text { pred. }\end{array}$ \\
\hline $\begin{array}{l}\text { Ischaemic } \\
\text { heart } \\
\text { disease, } \\
\text { including } \\
\text { myocardial } \\
\text { infarction }\end{array}$ & $\begin{array}{l}\text { Acceptable: } \\
\text { Medical treatment } \\
\text { and }>4 \text { months } \\
\text { asymptomatic } \\
\text { Unacceptable: } \\
\text { Cardiac symptoms or } \\
\text { signs of ischaemia in } \\
\text { ECG }\end{array}$ & $\begin{array}{l}\text { Acceptable: } \\
\text { Asymptomatic > } 6 \text { weeks; } \\
\text { certificate issued > } 6 \text { weeks } \\
\text { after invasive intervention; } \\
>12 \text { months if no invasive } \\
\text { intervention performed } \\
\text { Unacceptable: } \\
\text { Cardiac symptoms or signs } \\
\text { of ischaemia in ECG }\end{array}$ & $\begin{array}{l}\text { Acceptable: } \\
\text { Asymptomatic > } 3 \text { months } \\
\text { Unacceptable: } \\
\text { Cardiac symptoms or signs of } \\
\text { ischaemia in ECG }\end{array}$ & See UK \\
\hline Hypertension & $\begin{array}{l}\text { Acceptable: } \\
\text { No complications and } \\
\text { adequate therapy }\end{array}$ & $\begin{array}{l}\text { Acceptable: } \\
\text { < 140/90 mm Hg } \\
\text { Unacceptable: } \\
\text { Systole: > } 180 \mathrm{~mm} \mathrm{Hg} \text { and/ } \\
\text { /or diastole: > } 110 \mathrm{~mm} \mathrm{Hg} \\
\text { Individual assessment: } \\
\text { Systole: } 140-180 \mathrm{~mm} \mathrm{Hg} \\
\text { and/or diastole: } \\
90-110 \mathrm{~mm} \mathrm{Hg}\end{array}$ & $\begin{array}{l}\text { Acceptable: } \\
\text { No complications and adequate } \\
\text { therapy } \\
\text { Unacceptable: } \\
\text { 180/110 mm Hg with complications } \\
\text { Individual assessment: } \\
\text { Systole: } 140-180 \mathrm{~mm} \mathrm{Hg} \text { and/or } \\
\text { diastole: } 90-110 \mathrm{~mm} \mathrm{Hg}\end{array}$ & See UK \\
\hline $\begin{array}{l}\text { Insulin- } \\
\text {-dependent } \\
\text { diabetes } \\
\text { mellitus }\end{array}$ & $\begin{array}{l}\text { Generally not suitable } \\
\text { for unrestricted work } \\
\text { Acceptable: } \\
\text { If HbA1c in acceptable } \\
\text { range }>1 \text { year and no } \\
\text { complications }\end{array}$ & $\begin{array}{l}\text { Generally not suitable for } \\
\text { unrestricted work } \\
\text { Acceptable: } \\
\text { If free from hypoglycaemic } \\
\text { attacks and ketoacidosis } \\
>1 \text { year and no other risk } \\
\text { factors/complications; } \\
\text { HbA1c }<9 \% \text { for } 6 \text { months }\end{array}$ & $\begin{array}{l}\text { Generally not suitable for unrestricted } \\
\text { work; certificate valid for } 1 \text { year } \\
\text { Acceptable: } \\
\text { If free from hypoglycaemic attacks } \\
\text { and ketoacidosis }>1 \text { year and no } \\
\text { other risk factors/complications }\end{array}$ & $\begin{array}{l}\text { Generally not suitable for } \\
\text { unrestricted work; } \\
\text { certificate valid for } 1 \text { year; } \\
\text { only day shifts } \\
\text { Acceptable: } \\
\text { if free from hypoglycaemic } \\
\text { attacks and ketoacidosis } \\
>1 \text { year and no other risk } \\
\text { factors/complications }\end{array}$ \\
\hline Obesity & $\begin{array}{l}\text { Acceptable: } \\
\text { BMI } \leq 30 \\
\text { Unacceptable: } \\
\text { BMI > } 35 \\
\text { Individual assessment: } \\
\text { BMI 30-35, other risk } \\
\text { factors }\end{array}$ & $\begin{array}{l}\text { Acceptable: } \\
\text { BMI } \leq 35 \\
\text { Individual assessment: } \\
\text { BMI > 35: applicant must } \\
\text { be examined for medical } \\
\text { conditions (unacc. when } \\
>120 \mathrm{~kg},>115 \mathrm{~cm} \text { waist) }\end{array}$ & $\begin{array}{l}\text { Individual assessment: } \\
\text { Level of physical fitness } \\
\text { BMI > 40: } \\
\text { He/she can: } \\
\text { - Escape from a helicopter through } \\
\text { escape hatch } \\
\text { - Don and fasten standard lifejackets } \\
\text { over a survival suit } \\
\text { - Sit in a standard helicopter seat } \\
\text { and fasten a 3-point harness }\end{array}$ & $\begin{array}{l}\text { Acceptable: } \\
25<\mathrm{BMI}<30 \text {; } \\
\text { in case of } 30<\mathrm{BMI}<35 \text { : } \\
\text { fitness program } \\
\text { Unacceptable: } \\
\mathrm{BMI}>40 \\
\text { Individual assessment: } \\
35<\mathrm{BMI}<40 \text {, other risk; } \\
\text { fit to crawl through a "stan- } \\
\text { dard helicopter window" }\end{array}$ \\
\hline
\end{tabular}

to extrapolate $\mathrm{VO}_{2}$ max values from submaximal heart rate measurements. The relatively high margin of error, however, makes this form of testing more suitable for monitoring changes in fitness levels, as opposed to situations where an exact measure is needed (such as in occupational fitness testing) [26]. It would be interesting and useful, therefore, to explore other fitness testing options for such purposes.

\section{AN INTERNATIONAL GUIDELINE}

Upon thorough evaluation, it is clear that the British, Dutch, German and Norwegian offshore "Fitness to Work" guidelines are very similar, in structure, scope and content. One perhaps major difference lies in the choice of who conducts the examination, with Germany being the only country to require a physician who is a medical specialist in occupational medicine [16]. In some cases, such as in the UK, a qualified occupational nurse is suited to perform the examination [20]. In only a few of the medical categories do the countries provide varying recommendations for the discussed conditions, some of which are rather rare. It is interesting to note, however, that, in some cases, the guidelines do have considerably differing approaches to 
certain much more common conditions, including diabetes, obesity, ischaemic heart disease, pulmonary disease and psychiatric disorders (Table 1). It is possible that the varying work environments (e.g., location of the platform or absence or presence of qualified medical personnel and/or facilities) are in part responsible for these inconsistencies. Some offshore locations are actually "near offshore", such as is the case for many platforms in the UK, making it easier for workers to evacuate should an emergency arise. Another potential factor is the current workforce demographic for the offshore industry. As previously stated, the renewable energy sector is continually growing and advancing, at a rate that is difficult to keep up with in terms of employment and personnel. The vast majority of offshore wind energy workers is male, and has been working in the sector for no more than a decade at most [27]. This lack of experience, along with potential gender-associated risk factors or predispositions for certain medical conditions, could result in a greater or more varied risk profile. Furthermore, because the circumstances surrounding offshore wind work are so strenuous, both physically and psychologically, and because the pay cannot compete with that of the oil and gas industry, for example, the number of people willing to work in this sector may be rather low [27]. Finally, it is important to remember that three of the five discussed guidelines are intended for work in the oil and gas industry and, while very similar in terms of psychosocial risk factors and physical strain, these industries do present some important differences in workplace hazards.

The importance of regular evaluation (e.g., every 2 years) in such physically and psychologically demanding occupations must be stressed. The production of a document that is both stringent enough to allow for maximal safety, while also being fair, is largely dependent on the continual monitoring and acquisition of accident and illness statistics. Furthermore, the extent and appropriateness of the medical response in wind industry-specific emergency situations should similarly be catalogued and assessed (e.g., CeMOR in Germany and NOGEPA statistics, as yet unpublished) [13, 14]. A qualified, systematic documentation of critical incidents would provide more detailed insight into the dangers and problems employees in the offshore wind industry face.

\section{CONCLUSIONS}

Due to the similarities among the examined guidelines, as well as the current acceptance of medical certificates and basic safety training courses between certain countries, there is a great potential for a collaborative effort in the establishment of a single, internationally recognised document $[28,29]$. Certain areas still present a challenge, however, and will likely require more consultations and cooperation before a common accord acceptable to all can be reached. Indeed, there may initially be a few cases where workers will have to deal with "special requirements" in order to work in different jurisdictions (e.g., drug use or medications). Regardless, any such step in this direction would ease the process for current employees to relocate, potentially boost the workforce, and open many doors and opportunities for the further development of this exciting and important industry.

\section{CONFLICT OF INTEREST}

All authors declare that they have no conflicts of interest.

\section{REFERENCES}

1. Global oil and gas industry association for environmental and social issues (IPIECA) \& International Association of Oil \& Gas Producers (IOGP). Fitness to work: Guidance for company and contractor health, HSE and HR professionals. OGP Report No. 470. London 2011. http://www.ipieca.org/sites/default/files/publications/ Fitness_to_Work.pdf.

2. GWEC (Global Wind Energy Council). Global Wind Report: Annual Market Update 2014. http://www.gwec.net/wp-content/ uploads/2015/03/GWEC_Global_Wind_2014_Report_LR.pdf.

3. EWEA Business Intelligence. Aiming High. Rewarding Ambition in Wind Energy (November 2015) https://windeurope.org/fileadmin/ files/library/publications/reports/EWEA-Aiming-High.pdf.

4. Neslen A. Germany leads Europe in offshore wind energy growth (The Guardian, February 2nd, 2016) Retrieved September 6, 2016 from: https://www.theguardian.com/environment/2016/feb/02/ germany-leads-europe-in-offshore-wind-energy-growth.

5. Preisser AM, Toepel M, Harth V. Arbeitsmedizinische Eignungsuntersuchung für Mitarbeiter auf Offshoreinstallationen - Von der DGMM-Empfehlung zur AWMF-Leitlinie. Flugmed Tropenmed Reisemed 2016; 23: 14-18. doi:10.1055/s-0042-100759.

6. Parkes KR. Offshore working time in relation to performance, health and safety. A review of current practice and evidence. Prepared by the University of Oxford for the Health and Safety Executive (HSE) 2010. Research Report RR772. (http://www.hse.gov.uk/research/ rrpdf/rr772.pdf).

7. Mette J, Velasco Garrido M, Preisser AM, Harth V, Mache S. Psychische Belastung von Beschäftigten in der deutschen Offshore-Windindustrie. Zbl Arbeitsmed 2016; 66: 307-311. doi: 10.1007/ s40664-016-0131-7.

8. Preisser AM. Arbeiten auf den Windmühlen in der Nord- und Ostsee. Wer ist geeignet? AWMF-Leitlinie zu Eignungsuntersuchungen von Offshore-Mitarbeitern. Arbeitsmed Sozialmed Umweltmed 2015; 50: 871-874.

9. Jürgens $\mathrm{C}$, Weinrich N. Abschlussbericht - Erarbeitung eines Rettungskettenkonzepts für Unfallverletzte in Offshore-Windenergieanlagen. Berufsgenossenschaftliche Unfallklinik Hamburg (February 23, 2015). http://www.buk-hamburg.de/fileadmin/ Dateien/buk-hamburg/PDF/Content/05_Forschung/ABSCHLUSSBERICHT_ROW_FINAL.pdf.

10. Norman JN, Ballentine BN, Brebner JA et al. Medical Evacuations from Offshore Structures. Br J Ind Med. 1988; 45: 619-623.

11. Ponsonby W, Mika F, Irons G. Offshore Industry: Medical Emergency Response in the Offshore Oil and Gas Industry. Occup Med (Lond) 2009; 59: 298-303. doi: 10.1093/occmed/kqp075.

12. Thibodaux DP, Bourgeois RM, Loeppke RR, Konicki DL, Hymel PA, Dreger M. Medical evacuations from oil rigs off the Gulf Coast of the United States from 2008 to 2012: reasons and cost implica- 
tions. J Occup Environ Med 2014; 56: 681-685. doi: 10.1097/ JOM.0000000000000221.

13. Stuhr M, Dethleff D, Weinrich N, Nielsen MV, Hory D, et al. Vorläufige Auswertung: Medizinische Ereignisse in Offshore-Windparks - Erste Informationen zu Unfallverletzungen und Erkrankungen [Preliminary analysis: medical incidents in offshore wind farms - first information on injuries and illnesses]. Flug u Reisemed 2015; 22: 14-19. doi: 10.1055/s-0035-1547313.

14. Stuhr M, Dethleff D, Weinrich $N$ et al. Notfallmedizinische Versorgung in Offshore-Windparks. Neue Herausforderungen in der deutschen Nord- und Ostsee. [Medical Emergency Preparedness in offshore wind farms. New challenges in the german north and baltic seas.] Anaesthesist 2016; 65; 369-379. doi:10.1007/ s00101-016-0154-7.

15. Dethleff D, Weinrich N, Kowald B et al. Air Medical Evacuations From the German North Sea Wind Farm Bard Offshore 1: Traumatic Injuries, Acute Diseases, and Rescue Process Times (2011-2013). Air Med J 2016; 35: 216-226. doi: 10.1016/j.amj.2016.02.002.

16. DGAUM (Deutsche Gesellschaft für Arbeitsmedizin und Umweltmedizin). Arbeitsmedizinische Eignungsuntersuchung für Arbeitnehmer auf Offshore-Windenergieanlagen und anderen Offshore-Installationen (2015). Frankfurt: Association of the Scientific Medical Societies in Germany (AWMF) S1-Leitlinie 002/43. http://www.awmf.org/ uploads/tx_szleitlinien/002-043I_S1_Arbeitsmedizinische_Eignungsuntersuchung_Offshore_2015-02.pdf.

17. NOGEPA (Netherlands Oil and Gas Exploration and Production Association). Medical Aspects of Fitness to Work Offshore: Guidance for Examining Physicians. Industry Guideline no. 15. Version 2 (13-02-2013). http://www.nogepa.nl/en-us/download-guidelines.

18. Norwegian Directorate of Health. Guidelines to Regulations regarding health requirements for persons working on installations in petroleum activities offshore (02.2012/IS-1879). http://fylkesmannen. no/Documents/Dokument\%20FMRO/Helse\%20og\%20sosial/ Regelverk\%20og\%20styringsdokument/IS-1879\%20Guidelines\%20 to $\% 20$ Regulations $\% 20$ regarding\%20health\%20requirements $\% 20$ for $\% 20$ offshore\%20workers.pdf.

19. Taylor J. Medical Aspects of Fitness for Work Offshore: Guidance for Examining Physicians - Issue 6. London: Oil \& Gas UK 2008. http:// oilandgasuk.co.uk/product/medical-aspects-of-fitness-for-offshore -work-guidance-for-examining-physicians-issue-6-cd-rom/.
20. RenewableUK. Medical Fitness to Work - Wind Turbines: Guidelines for near offshore and land based projects. Health and Safety 2013; 2. http://www.ddrc.org/uploads/medical_fitness_to_work_54918.pdf.

21. EWEA (The European Wind Energy Association). The European Offshore Wind Industry - Key Trends and Statistics 2014. Report January 2015. http://www.ewea.org/fileadmin/files/library/publications/statistics/EWEA-European-Offshore-Statistics-2014.pdf.

22. FOCUS online. Nordsee-Windpark: Die Größte deutsche Baustelle im Meer. (August 12, 2011). http://www.focus.de/wissen/ klima/nordsee-windpark-die-groesste-deutsche-baustelle-im-meer_aid_654673.html.

23. Ocean Breeze Energy GmbH \& Co KG. http://www.oceanbreeze. de/en/technology.

24. Sykes K, Roberts A. The Chester step test - a simple yet effective tool for the prediction of aerobic capacity. Physiotherapy 2004; 90 : 183-188. doi: 10.1016/j.physio.2004.03.008.

25. Latin RW, Berg K, Kissinger K, Sinnett A, Parks L. The accuracy of the ACSM stair-stepping equation. Med Sci Sports Exerc 2001; 33: $1785-1788$.

26. Buckley JP, Sim J, Eston RG, Hession R, Fox R. Reliability and validity of measures taken during the Chester Step Test to predict aerobic power and to prescribe aerobic exercise. Br J Sports Med 2004; 38 : 197-205. doi: 10.1136/bjsm.2003.005389.

27. EU-OSHA (European Agency for Safety and Health at Work). Occupational safety and health in the wind energy sector. European Risk Observatory. Report, 2013. https://osha.europa.eu/en/ tools-and-publications/occupational-safety-and-health-in-the-wind-energy-sector.

28. Norwegian Oil and Gas Association. (2014, September 01). Guidelines for Mutual Recognition of Specialised Safety and Emergency Response Training for North Sea Operations. https://www.norskoljeoggass.no/Global/Guidelines\%20of\%20Mutual\%20Recognition\%20 of $\% 20$ Specialised\%20Safety\%20and\%20Emergency\%20Response\%20Training\%20rev\%204\%202013.pdf?epslanguage=en .

29. Nederlandse Olie en Gas, Norwegian Oil \& Gas, Oil \& Gas Denmark, and Oil \& Gas UK. Mutual Recognition of Basic Safety and Emergency Response (Revised September $1^{\text {st }}$, 2014). http://www.dhtc. $\mathrm{nl} /$ files/Info\%20Nederlands\%20algemeen\%20PDF/Appendix\%20 1\%20Mutual\%20recognition\%20of\%20Basic\%20Safety\%20\&\%20 Emerg.\%20Preparedness\%20Training\%20Rev.\%2001-10-2014.pdf. 